\title{
Initial Characterization of Transgenic Mice Overexpressing Human Histamine $\mathrm{H}_{2}$ Receptors
}

\author{
U. Gergs, G. Bernhardt, I. B. Buchwalow, H. Edler, J. Fröba, M. Keller, U. Kirchhefer, \\ F. Köhler, N. Mißlinger, H. Wache, and J. Neumann \\ Institute for Pharmacology and Toxicology, Medical Faculty, Martin Luther University Halle-Wittenberg, Halle (Saale), Germany \\ (U.G., H.E., J.F., F.K., N.M., H.W., J.N.); Institute of Pharmacy, University of Regensburg, Regensburg, Germany (G.B., M.K.); \\ Institute for Hematopathology, Hamburg, Germany (I.B.B.); and Institute for Pharmacology and Toxicology, University Hospital \\ Münster, Westfälische Wilhelms-University, Münster, Germany (U.K.)
}

Received December 11, 2018; accepted January 25, 2019

\section{ABSTRACT}

In an integrative approach, we studied the role of histamine $\mathrm{H}_{2}$ receptors in the mouse heart. We noted that histamine, added cumulatively to the organ bath, failed to affect the force of contraction in left atrial preparations and did not change spontaneous heart rate in right atrial preparations from wildtype mice. By contrast, in the same preparations from mice that overexpressed the human $\mathrm{H}_{2}$ receptor in a cardiac-specific way, histamine exerted concentration- and time-dependent positive inotropic and positive chronotropic effects. Messenger RNA of the human $\mathrm{H}_{2}$ receptor was only detected in transgenic mice. Likewise, immunohistology and autoradiography only gave signals in transgenic but not in wild-type cardiac preparations. Similarly, a positive inotropic and positive chronotropic effect was observed with histamine in echocardiography of living transgenic mice and isolated perfused hearts (Langendorff preparation). Phosphorylation of phospholamban was increased in atrial and ventricular preparations from transgenic mice, but not in wild-type animals. The effects of histamine were mimicked by dimaprit and amthamine and antagonized by cimetidine. In summary, we generated a new model to study the physiologic and pathophysiologic cardiac role of the human $\mathrm{H}_{2}$ receptor.

\section{Introduction}

Histamine is a naturally occurring monoamine that has been studied for many years as a neurotransmitter (Parsons and Ganellin, 2006; Haas et al., 2008). The group of Sir Henry Hallet Dale in Oxford (Dale and Laidlaw, 1910) was the first to publish a study on the positive inotropic effect [(PIE), increase in force] and positive chronotropic effect (PCE) of histamine (Dale and Laidlaw, 1910), which was confirmed later (Einis, 1913). Cardiovascular effects of histamine were different between species and anatomic regions. For instance, histamine in rabbit coronary arteries led to vasoconstriction, whereas histamine relaxed other arterial vessels measured as hypotension in cat, dog, guinea pig (Dale and Laidlaw, 1910, 1911), and human (Schenk, 1921).

Histamine was synthesized at the University of Freiburg, in Freiburg, Germany (Windaus and Vogt, 1907). Others at the same university described the degradation of histidine to histamine by bacteria (Ackermann, 1910), suggesting that histamine could be formed in vivo. Currently, the effects of histamine are thought to be mediated by just four receptors known as $\mathrm{H}_{1}, \mathrm{H}_{2}, \mathrm{H}_{3}$, and $\mathrm{H}_{4}$ histamine receptors (Jutel et al., 2009). These histamine receptors have been extensively studied in the central nervous system, where histamine is

https://doi.org/10.1124/jpet.118.255711. generated in specific cells and can then act as a neurotransmitter in histaminergic neurons (for a review, see Seifert et al., 2013; Panula et al., 2015). Less is known about histamine and histamine receptors in peripheral tissue such as the heart than in the central nervous system. In the heart, all four histamine receptor subtypes have been described on the RNA and/or protein level. In the mouse heart, a direct histamine receptor-mediated inotropic or chronotropic effect is missing (this study), which motivated us to construct a $\mathrm{H}_{2}$ receptor-expressing transgenic mouse (this study). First, there have been reports on a PIE in the mouse left atrium (Liu et al., 2002), a negative inotropic effect in the mouse left atrium mediated by $\mathrm{H}_{1}$ and $\mathrm{H}_{2}$ receptors, a PCE via $\mathrm{H}_{2}$ receptors (Goren et al., 1994, 1995), and a negative inotropic effect in the mouse ventricle via $\mathrm{H}_{2}$ receptors (Goren et al., 1994, 1995). Second, histamine may have a functional cardiac effect, but this effect may be histamine receptor independent. For example, in the rat, dog, and cat, inotropic effects of histamine were found to be indirect (Bartlet, 1963; Flacke et al., 1967; Dai, 1976; Wellner-Kienitz et al., 2003), that is, via release of endogenous catecholamines (Laher and McNeill, 1980a,b).

Third, even regional differences in the actions of histamine or histamine receptor utilization of histamine in the mammalian heart are known: in rabbit atrium, $\mathrm{H}_{1}$ receptors are more prevalent and a PIE mediated by $\mathrm{H}_{1}$ and phospholipase $\mathrm{C}$ activation has been described in Hattori et al. (1988) (see the scheme Fig. 1) and Hattori et al. (1990, 1991). In humans, $H_{1}$ 
and $\mathrm{H}_{2}$ receptors were detected early on in the atrium and ventricle [for radioligand binding, see Baumann et al. (1982, 1983, 1984); for antibody and RNA expression, see Matsuda et al. (2004)]. In humans, the cardiac $\mathrm{H}_{2}$ receptors were described to mediate the PIE of exogenously applied histamine in isolated human cardiac preparations (Levi et al., 1981; Genovese et al., 1988; Zerkowski et al., 1993; Sanders et al., 1996; Thoren et al., 2011). These PIEs in the human heart were accompanied by-and, hence, probably mediated by-an increase in cAMP [for human right atrial preparations, see Sanders et al. (1996)] and opening of L-type $\mathrm{Ca}^{2+}$ channels (Eckel et al., 1982). Hence, the mode of action of $\mathrm{H}_{2}$ receptors in the human heart mimics the $\beta$-adrenoceptor system in the human heart. $\mathrm{H}_{1}$ receptors were described to mediate negative chronotropic effects in isolated human atrial preparations (Genovese et al., 1988). In surgically obtained ventricular tissue from one patient, histamine stimulated adenylyl cyclase activity in a seminal paper (Klein and Levey, 1971) (see, also, Fig. 1). Infusion of histamine in patients led to an increase in heart beat and an increase in the first derivative of pressure development in the left ventricle (Vigorito et al., 1983). $\mathrm{H}_{3}$ and $\mathrm{H}_{4}$ receptors are present in the mouse (Koyama et al., 2003; Aldi et al., 2014) and human heart (Aldi et al., 2014), but are localized in cardiac neurons, where their stimulation can inhibit the cardiac release of noradrenaline, and thus may play a cardioprotective role.

Here, we set out to generate and describe a transgenic mouse model with cardiac-specific expression of the human $\mathrm{H}_{2}$ receptor. Initial data were published in abstract form (Köhler et al., 2013; Neumann et al., 2013, 2014, 2015; Meister et al., 2014, 2015).

\section{Materials and Methods}

Transgenic Mice. The investigation conforms to the Guide for the Care and Use of Laboratory Animals published by the National Research Council (2011). Animals were maintained and handled according to approved protocols of the animal welfare committees of the University of Münster and the University of Halle-Wittenberg.

The plasmid, containing the human $\mathrm{H}_{2}$ receptor cDNA (GeneBank Accession Number AY136744), was kindly provided by R. Seifert (Institute of Pharmacology, Hannover Medical School, Hannover, Germany). The $\mathrm{H}_{2}$ receptor cDNA together with a C-terminal 6xHistidin tag was excised out of the parent plasmid by Hind III and XbaI, the endings of the fragment were blunted by Klenow polymerase, and finally inserted into the $E c o$ ICR site of a mouse cardiac $\alpha$-myosin heavy chain promoter expression cassette. The orientation of the cDNA was confirmed by sequencing. The $\mathrm{H}_{2}$ receptor cDNA promoter construct was digested with $\mathrm{Nru}$ I and purified by cesium chloride gradient centrifugation for injection into the pronuclei of single-cell fertilized mouse embryos. Generation of transgenic (TG) mice was performed by standard procedures (mouse strain: FVB/N). Several transgenic lines overexpressing the $\mathrm{H}_{2}$ receptor under control of the $\alpha$-myosin heavy chain promoter were established, one of which was investigated further and is described in the present study. Other founders had no inotropic response to histamine: one was responsive to histamine but did not give the transgene to the offspring, and others had no offspring. The TG line studied here was crossed to CD1 background. Genotypes were identified by polymerase chain reaction (PCR) analyses of tail tip DNA using the following primers: $5^{\prime}$-ACCCTTACCCCACATAGACC-3' and 5'AGCAGGTCAGTGATAGCCAA-3'. The PCR reaction was performed using Ampliqon Taq DNA Polymerase (Biomol, Hamburg, Germany) according to the manufacturer's instructions. In all experiments, 12 - to 30 -week-old TG mice and wild-type (WT) littermates of both sexes were used.
Western Blot Analysis. Homogenates from ventricular tissue samples were prepared in $300 \mu \mathrm{l}$ of $10 \mathrm{mM} \mathrm{NaHCO}_{3}$ and $100 \mu \mathrm{l} 20 \%$ SDS. Crude extracts were incubated at $25^{\circ} \mathrm{C}$ for 30 minutes before centrifugation to remove debris, and then the supernatants (= homogenates) were separated and stored at $-80^{\circ} \mathrm{C}$ until further use. Western blot analysis was performed as previously described (Gergs et al., 2004). Briefly, aliquots of $100 \mu \mathrm{g}$ of protein were loaded per lane, and finally bands were detected using enhanced chemifluorescence (GE Healthcare Europe, Freiburg, Germany) together with a Typhoon 9410 Variable Mode Imager (GE Healthcare Europe). The following primary antibodies were used in this study: polyclonal rabbit anticalsequestrin (Acris Antibodies, Hiddenhausen, Germany), antiphosphatase-inhibitor-1 antiboby (ab84477; Abcam, Cambridge, UK), monoclonal mouse anti-SERCA2a (kindly provided by L. R. Jones, Indianapolis, IN), monoclonal mouse anti-phospholamban (PLB) (A-1; Badrilla, Leeds, UK), and polyclonal rabbit anti-phospho-PLB (antibodies were raised against PLB-peptide phosphorylated at serine-16 or threonine-17; Badrilla). The characteristics and use of these antibodies has been reported repeatedly by our group (Kirchhefer et al., 2002). The antibodies against TnI and phospho-TnI were obtained from GE Healthcare, and the antibodies against $\alpha$-subunits of $\mathrm{G}_{\mathrm{i}}$-protein and $\mathrm{G}_{\mathrm{s}}$-protein were purchased from Calbiochem (Darmstadt, Germany).

Histologic Analysis. Hearts were fixed in buffered 4\% formaldehyde and embedded in paraffin. Four micron sections were mounted on polylysine microslides. Immunodetection of $6 x$ Histidin-tag was performed using rabbit polyclonal antibodies to 6xHistidin-tag [Hisprobe (H-15) sc-803; Santa Cruz, Heidelberg, Germany]. For immunohistochemical assays, deparaffinized sections were subjected to antigen retrieval by heating the sections in $10 \mathrm{mM}$ sodium citrate buffer, $\mathrm{pH} 6.0$, at $95^{\circ} \mathrm{C}$ for 30 minutes in a domestic vegetable steamer. Thereafter, sections were immunoreacted with primary rabbit antibodies to $6 \mathrm{xHistidin}$-tag overnight at $4^{\circ} \mathrm{C}$. Primary antibodies were diluted in PBS 1:50. After immunoreacting with primary antibodies and subsequent washing in PBS, sections were treated with methanol containing $0.6 \% \mathrm{H}_{2} \mathrm{O}_{2}$ for 10 minutes to quench endogenous peroxidase. Bound primary antibodies were detected with the AmpliStain heteropolymeric horseradish peroxidase detection system manufactured by Stereospecific Detection Technologies (SDT GmbH, Baesweiler, Germany) (Buchwalow et al., 2011). The horseradish peroxidase label was visualized using the NovaRed substrate kit (Vector Laboratories, Burlingame, CA). Immunostained sections were examined on a Zeiss Axio Imager Z1 microscope. Microscopy images were captured using AxioCam digital microscope cameras and AxioVision image processing (Carl Zeiss Vision, Oberkochen, Germany). The images were acquired at 96 dots per inch and submitted with the final revision of the manuscript at 300 dots per inch. Images shown are representative of three independent experiments that gave similar results.

Autoradiography. Autoradiography at cryosections $(12 \mu \mathrm{m})$ of Langendorff-perfused mouse hearts (frozen in Tissue-Tek; Sakura Europe, Alphen aan den Rijn, The Netherlands) was essentially performed according to a previously described procedure (Keller et al., 2008). Leibovitz's L15 medium with L-glutamine (Gibco, Paisley, Scotland) supplemented with $1 \%$ bovine serum albumin was used as the binding buffer. Slides with mounted cryosections were immediately placed in a chamber at $100 \%$ humidity and covered with binding buffer. After 10-15 minutes, the binding buffer was carefully removed, followed by covering the sections with binding buffer containing the selective $\mathrm{H}_{2}$ receptor antagonist $\left[{ }^{3} \mathrm{H}\right] \mathrm{UR}-\mathrm{DE} 257$ (Baumeister et al., 2015) (30 nM) (total binding) or binding buffer containing $\left[{ }^{3} \mathrm{H}\right] \mathrm{UR}-\mathrm{DE} 257(30 \mathrm{nM})$ and the histamine $\mathrm{H}_{2}$ receptor antagonist famotidine ( $9 \mu \mathrm{M})$ (unspecific binding). The sections were incubated in a humidity chamber at room temperature for 60 minutes, followed by a previously described washing and drying procedure (Keller et al., 2008). Images were acquired after incubation of the slides on a tritium-sensitive phosphor screen (PerkinElmer) for 21 days. 


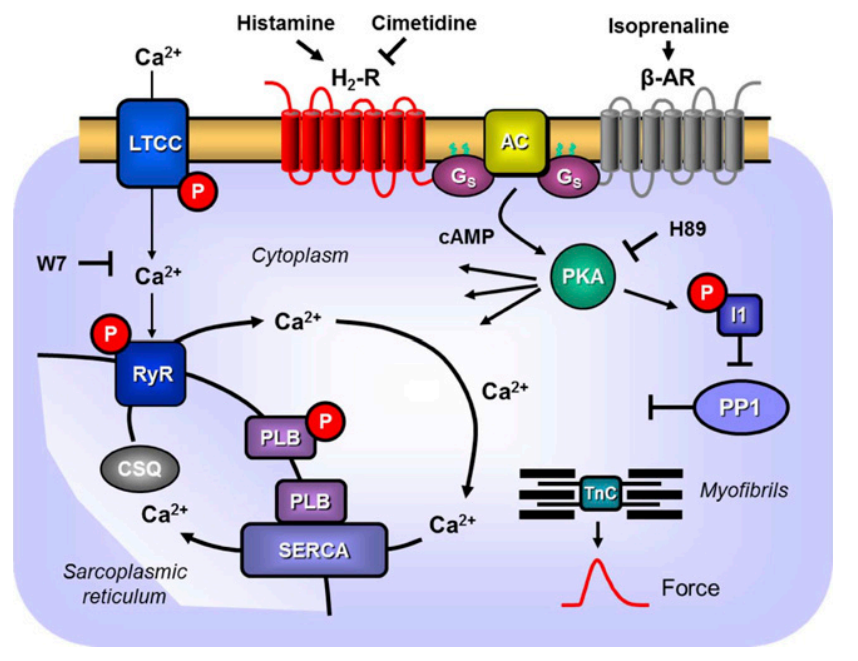

Signal transduction via
$\mathrm{H}_{2}$-receptors in cardiomyocytes.

$\begin{array}{ll}\text { AC } & : \text { Adenylyl cyclase } \\ \beta-A R & : \beta \text { - Adrenoreceptor } \\ \text { CSQ } & : \text { Calsequestrin } \\ \text { Gs } & : \text { Stimulatory G-protein } \\ \text { I1 } & : \text { Protein phosphatase inhibitor 1 } \\ \text { LTCC } & : \text { L-type calcium channel } \\ \text { P } & \text { : Phosphorylation } \\ \text { PKA } & \text { : Protein kinase A } \\ \text { PLB } & \text { : Phospholamban } \\ \text { PP1 } & \text { : Protein Phosphatase 1 } \\ \text { RyR } & \text { : Ryanodine receptor } \\ \text { SERCA } & \text { : SR calcium ATPase } \\ \text { TnC } & \text { : Troponin C }\end{array}$

Schematic diagram of the
transgenic construct

Fig. 1. Scheme and schematic diagram of the transgenic construct.

Echocardiography. Echocardiography in spontaneously breathing mice was performed under anesthesia with $1.5 \%$ isoflurane as described previously (Gergs et al., 2010).

Hemodynamic Measurements by Left-Ventricular Catheterization. Mice were anesthetized by intraperitoneal injection of avertin (2,2,2-tribromoethanol; Sigma-Aldrich, Hamburg, Germany) in $2 \%$ solution at a dose of $400 \mathrm{mg} / \mathrm{kg}^{-1}$ bodyweight and placed on a controlled heating pad in supine position. Additional doses of avertin (each $10 \%$ of the initial dose) were applied during the experiments if appropriate to maintain depth of anesthesia. A 0.5 - $\mathrm{mm}$ polyethylene catheter connected to a fluid-filled disposable pressure transducer was inserted via the right carotid artery and placed in the left ventricle. Histamine was administered into the cannulated left external jugular vein using an automated syringe pump (B. Braun, Melsungen, Germany). Data were recorded and digitized at a sampling rate of $1000 \mathrm{~Hz}$ with the PowerLab system (ADInstruments, Spechbach, Germany). At the end of the experiments, animals were euthanized by an avertin overdose, and hearts were excised, weighed, and stored at $-80^{\circ} \mathrm{C}$ until further examination. Hemodynamic data were analyzed using Chart5 software (ADInstruments).

Isolation of Cardiomyocytes. Ventricular cardiomyocytes were isolated similarly to a published protocol (Kirchhefer et al., 2002). In brief, hearts were perfused at $2 \mathrm{ml} / \mathrm{min}^{-1}$ with $\mathrm{Ca}^{2+}$-free Hanks' balanced salt solution (Gibco) for 6 minutes, followed by perfusion with Hanks' balanced salt solution supplemented with 1495 U collagenase (type 2; Worthington, Lakewood, NJ) and 5 U protease (Type XIV; Sigma-Aldrich) for 6 minutes. After enzymatic digestion, the hearts were perfused with Hanks' balanced salt solution containing $90 \mu \mathrm{M}$ $\mathrm{Ca}^{2+}$ for 6 minutes, and ventricles were cut into several pieces before myocytes were separated by filtration through a $70-\mu \mathrm{m}$ nylon mesh (Corning Incorporated, Durham, NC).

Edge Detection and Measurement of Calcium Transients. Measurement of cell shortening of isolated cardiomyocytes was done as previously described (Gergs et al., 2007). Cells were electrically stimulated ( $1 \mathrm{~Hz}, 100 \mathrm{~V}, 6$ milliseconds), and as a parameter of contractility the shortening of the cell length was determined with a video edge detector (VED 105; Crescent Electronics, Sandy, UT) combined with PTI Felix32 software (Photon Technology International, Birmingham, NJ). After recording basal cell shortening, cardiomyocytes were treated with $10 \mu \mathrm{M}$ histamine, $10 \mu \mathrm{M}$ histamine $+100 \mu \mathrm{M}$ cimetidine, or $1 \mu \mathrm{M}$ isoprenaline (positive control), and the difference in cell shortening in relation to the baseline was determined. Calcium transients were measured in isolated and electrically stimulated cardiomyocytes ( $1 \mathrm{~Hz}, 100 \mathrm{~V}, 6$ milliseconds) by a modified protocol described in Gergs et al. (2011). The cells were labeled with $2 \mu \mathrm{M}$ Fluo4-AM (Thermo-Fisher, Karlsruhe, Germany) according to the manufacturer's recommendations and analyzed with a confocal laser scanning microscope (AxioObserver, Zeiss, Oberkochen, Germany) combined with a Vt-Eye system (VisiTech International, Sunderland, UK). After recording basal calcium transients, cells were treated with $10 \mu \mathrm{M}$ histamine, $10 \mu \mathrm{M}$ histamine $+100 \mu \mathrm{M}$ cimetidine, or $1 \mu \mathrm{M}$ isoprenaline (positive control). The measured fluorescence intensities were analyzed with MetaMorph software (Molecular Devices, Ismaning, Germany) and the differences in average fluorescence intensity in relation to the basal calcium transients were determined.

Contractile Function. Mice were anesthetized by intraperitoneal injection of pentobarbital sodium $\left(50 \mathrm{mg} / \mathrm{kg}^{-1}\right)$ and hearts were excised. Right and left atria were dissected from isolated $\mathrm{H}_{2}$ receptors in the hearts of TG and WT mice and mounted in an organ bath. Left atrial preparations were continuously electrically stimulated (field stimulation), with each impulse consisting of $1 \mathrm{~Hz}$ at a voltage of $10 \%-$ $15 \%$ above threshold and 5-millisecond duration. Right atrial preparations were allowed to contract spontaneously. The bathing solution contained $119.8 \mathrm{mM} \mathrm{NaCI}, 5.4 \mathrm{mM}$ KCI, $1.8 \mathrm{mM} \mathrm{CaCl}_{2}, 1.05 \mathrm{mM}$ $\mathrm{MgCl}_{2}, 0.42 \mathrm{mM} \mathrm{NaH}_{2} \mathrm{PO}_{4}, 22.6 \mathrm{mM} \mathrm{NaHCO}_{3}, 0.05 \mathrm{mM} \mathrm{Na}_{2}$ EDTA, $0.28 \mathrm{mM}$ ascorbic acid, and $5.0 \mathrm{mM}$ glucose, and was continuously gassed with $95 \% \mathrm{O}_{2}$ and $5 \% \mathrm{CO}_{2}$ and maintained at $35^{\circ} \mathrm{C}$, resulting in a $\mathrm{pH}$ of 7.4. Signals detected via an isometric force transducer were amplified and continuously recorded.

Langendorff-Perfused Hearts. Heart preparations were used as described previously (Kirchhefer et al., 2014). Mice were anesthetized by intraperitoneal injection of pentobarbital sodium $\left(50 \mathrm{mg} / \mathrm{kg}^{-1}\right)$ and hearts were excised. The hearts were removed from the opened chest, immediately attached by the aorta to a 20 -gauge cannula, and perfused retrogradely under a constant flow of $2 \mathrm{ml} / \mathrm{min}^{-1}$ with oxygenized buffer solution $\left(37^{\circ} \mathrm{C}\right)$ containing $119.8 \mathrm{mM} \mathrm{NaCI}$, $5.4 \mathrm{mM} \mathrm{KCI}, 1.8 \mathrm{mM} \mathrm{CaCl}_{2}, 1.05 \mathrm{mM} \mathrm{MgCl}, 0.42 \mathrm{mM} \mathrm{NaH}_{2} \mathrm{PO}_{4}$, $22.6 \mathrm{mM} \mathrm{NaHCO}{ }_{3}, 0.05 \mathrm{mM} \mathrm{Na} 2$ EDTA, $0.28 \mathrm{mM}$ ascorbic acid, and $5.0 \mathrm{mM}$ glucose in an isolated heart system (Hugo Sachs Elektronik, March-Hugstetten, Germany). The heart preparations were allowed to equilibrate for 30 minutes before measurements. Hearts were stimulated at $8 \mathrm{~Hz}$ and heart rate, aortic pressure, and left ventricular pressure were measured and monitored continuously. The first derivative of left ventricular pressure $(+\mathrm{dP} / \mathrm{dt}$ and $-\mathrm{dP} / \mathrm{dt})$ was calculated (ISOHEART Software; Hugo Sachs Elektronik). 
Data Analysis. Data shown are mean \pm S.E.M. Statistical significance was estimated by ANOVA, followed by Bonferroni's $t$ test or using the $\chi^{2}$-test as appropriate. A value of $P<0.05$ was considered significant.

Drugs and Materials. All other chemicals were of analytical grade. Demineralized water was used throughout the experiments. Stock solutions were freshly prepared daily.

\section{Results}

Utilizing immunohistology (Fig. 2A) we noted distinct signals in samples from hearts of TG animals, in contrast to samples from WT hearts. Similarly, we noted in real-time PCR, mRNA from TG hearts using primers specific for the human $\mathrm{H}_{2}$ signals (data not shown). In western blotting with commercially available antibodies we failed to detect differences between TG and WT (data not shown). We detected signals for mouse $\mathrm{H}_{2}$ receptors in PCR in both WT and TG (data not shown). We failed to detect specific radioligand binding, starting either with homogenates from hearts of TG or preparations enriched for membranes of hearts of TG. However, we succeeded in performing autoradiography with the selective $\mathrm{H}_{2}$ receptor ligand $\left[{ }^{3} \mathrm{H}\right] \mathrm{UR}-\mathrm{DE} 257$ in the heart sections of TG mice (see Fig. 2B). Quantification of the data revealed a higher level of $\mathrm{H}_{2}$ receptor expression in atrium than in ventricle of TG (Table 1). Data for WT are also presented and are tentatively regarded at background signals (Fig. 2B; Table 1).

In isolated left atrial preparations (electrically driven), we noted no effect of histamine on force of contraction when histamine was cumulatively applied from 0.1 to $10 \mu \mathrm{M}$ from WT siblings of TG animals (Fig. 3A, lower original recording). In contrast, in isolated left atrial preparations (electrically driven) from TG, we noted concentration-dependent PIEs when histamine was cumulatively applied from 0.1 to $10 \mu \mathrm{M}$ (Fig. 3A, upper original recording). Data are summarized in Fig. 3B. Moreover, the concentration-dependent effect of histamine on force of contraction in TG could be attenuated by cimetidine, a typical $\mathrm{H}_{2}$ receptor inverse agonist (or antagonist) (see original recording in Fig. $3 \mathrm{C}$ and summarized data in Fig. 3D). Similarly, in spontaneously contracting right atrial preparations from WT mice, we did not note any effect on beating rate when the $\mathrm{H}_{2}$ agonist dimaprit was cumulatively applied from 0.1 to $10 \mu \mathrm{M}$ (data not shown). Dimaprit and amthamine are more selective agonists at $\mathrm{H}_{2}$ receptors than histamine (which acts as an agonist at all four histamine receptors). Using amthamine, in isolated left atrial preparations (electrically driven) from TG, we noted a concentrationdependent PIE to amthamine (0.1-10 $\mu \mathrm{M}$, Fig. 3E). Moreover, cimetidine was able to shift the concentration response curve of histamine and dimaprit in left and right atrial preparations of TG to higher concentrations of histamine (rightward shift) (original recordings of left atrial preparations: Fig. 3, A, C, G, and I; summarized data: Fig. 3, D and H). Likewise, the PIE of dimaprit was antagonized in left atrial preparations from TG by cimetidine (Fig. $3 \mathrm{H}$ ). Of note, the concentration-response curve for the PIEs of dimaprit and histamine in left atrial TG preparations was superimposable, arguing for the similar potency and efficacy of these drugs (Fig. 3F). Of note, in Fig. 3, $\mathrm{F}$ and $\mathrm{H}$ in WT one might detect at first glance an apparent negative inotropic effect of histamine and dimaprit. However, we chose here to present the results over time without correction for time effects. We also performed time control experiments where atrial preparations of WT were not treated with drugs. We saw a similar decrease in force (data not shown), which is strong evidence that in WT there is neither a positive nor a negative inotropic effect of histamine and dimaprit. One can even argue that we are on the safe side and are underestimating the effects of histamine and dimaprit in TG atrial preparations.

Next, it was of interest to investigate ventricular effects of histamine. To that end, we used isolated retrogradely perfused hearts (Langendorff preparations). These preparations were allowed to beat spontaneously. We recorded force of contraction from the apex; therefore, under these conditions we measured ventricular function (original recording). We noted that $1 \mu \mathrm{M}$ histamine increased force of contraction in hearts from TG but not WT (Fig. 4A, original recording). As a positive control, we studied the effects of isoprenaline, a typical agonist at $\beta$-adrenoceptors. As expected, it was able
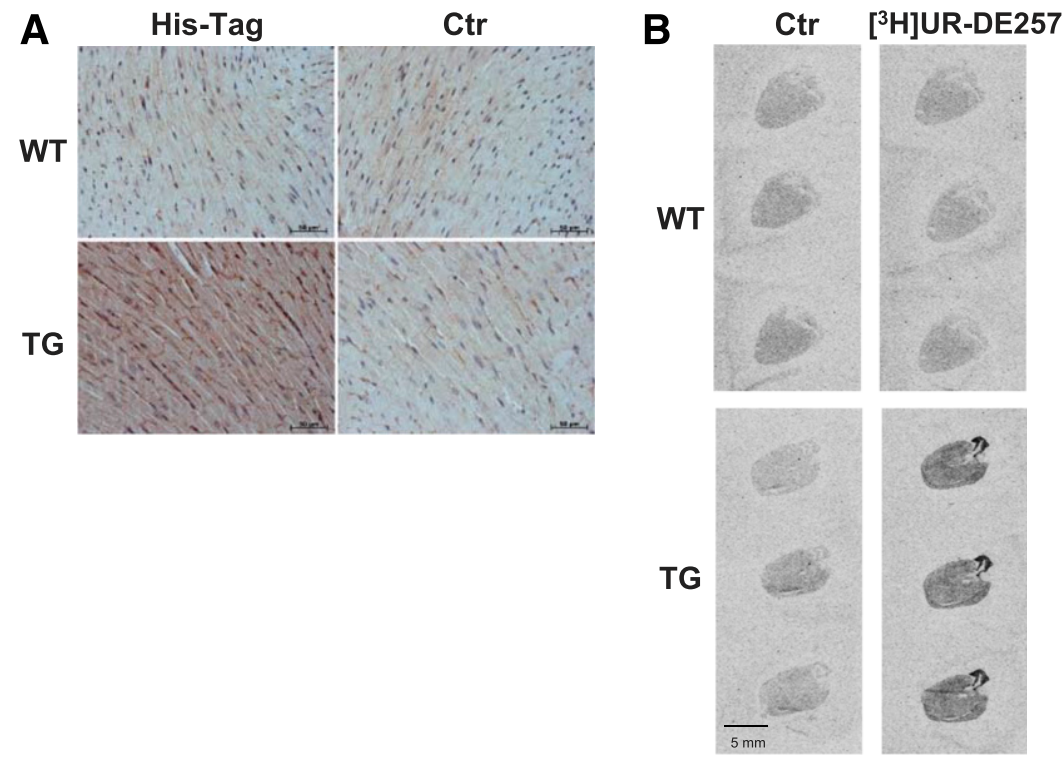

Fig. 2. (A) Immunodetection of the His-tag in histologic sections of mouse hearts. As control (Ctr), tissue was incubated with peptide-blocked antibodies. (B) Representative images of autoradiography of WT and TG mouse heart sections labeled with $30 \mathrm{~nm}$ of the $\mathrm{H}_{2}$ receptor-specific ligand $\left[{ }^{3} \mathrm{H}\right] \mathrm{UR}-\mathrm{DE} 257$ or $30 \mathrm{nM}\left[{ }^{3} \mathrm{H}\right] \mathrm{UR}-\mathrm{DE} 257+9 \mu \mathrm{M}$ famotidine as unspecific control. 
TABLE 1

Average intensity of autoradiography signals of WT and TG mouse heart sections labeled with $30 \mathrm{~nm}\left[{ }^{3} \mathrm{H}\right]$ UR-DE257 or $30 \mathrm{nM}\left[{ }^{3} \mathrm{H}\right]$ UR-DE257 + $9 \mu \mathrm{M}$ famotidine as unspecific control

WT: $N / n=2 / 7-12$, TG: $N / n=2 / 9$, mean \pm S.E.M., ANOVA, ${ }^{*} P<0.05$ vs. corresponding control TG, ${ }^{\#} P<0.05$ vs. same treatment WT.

\begin{tabular}{|c|c|c|c|c|}
\hline \multirow{2}{*}{ Average Intensity ${ }^{a}$} & \multicolumn{2}{|c|}{ Atrium } & \multicolumn{2}{|c|}{ Ventricle } \\
\hline & Control & {$\left[{ }^{3} \mathrm{H}\right] \mathrm{UR}-\mathrm{DE} 257$} & Control & {$\left[{ }^{3} \mathrm{H}\right]$ UR-DE257 } \\
\hline WT & $93.5 \pm 1.4$ & $98.6 \pm 3.5$ & $97.4 \pm 1.6$ & $101.1 \pm 1.4$ \\
\hline TG & $84.4 \pm 0.8$ & $194.3 \pm 3.3^{*, \#}$ & $89.5 \pm 1.9$ & $124.4 \pm 1.5^{*, \#}$ \\
\hline
\end{tabular}

${ }^{a}$ In arbitrary units.

to increase force of contraction (Fig. 4B) in isolated perfused hearts from WT as well as TG. Moreover, we could show that cimetidine (as in the atrium) was able to block the PIE in TG but was ineffective in WT (Fig. 4B). We additionally studied spontaneous left ventricular force of contraction in isolated hearts. We noted that basal force was unaltered between TG and WT (Fig. 4C). Stimulation by histamine was able to increase left ventricular force of contraction in TG but not in WT (Fig. 4B). The PIE of histamine in TG was completely absent if cimetidine was applied together with histamine (Fig. 4B).

Furthermore, it was of interest to study the effects of histamine in vivo. To that end, we performed invasive hemodynamic measurements (measurement of pressure in the left ventricle) in the anesthetized living animal. After intraperitoneal injection of histamine $(100 \mu \mathrm{l}$ of $10 \mathrm{mM}$ solution of histamine), we noted an increase in cardiac contractility that was indicated, for instance, by an increased first positive derivative of pressure in TG mice to $133 \% \pm 12 \%$ and was absent in WT mice $(P<0.05 ; n=5-7)$.

To investigate the effects of the $\mathrm{H}_{2}$ receptor on cardiovascular performance in vivo, we performed echocardiographic measurements in TG and WT mice under isoflurane anesthesia. We noted that dimaprit injected intraperitoneally (100 $\mu \mathrm{l}$ of a $10 \mathrm{mM}$ solution) increased the left ventricular ejection fraction and beating rate in TG (Fig. 5, A and B). Furthermore, using echocardiography we studied the typical dimensions of the heart such as the left ventricular systolic and diastolic diameters under basal and dimaprit-stimulated conditions. We noted substantial increases in these parameters after injection of dimaprit in TG but not WT (original M-mode recordings, Fig. 5C). The effects of dimaprit were blocked by the simultaneously applied cimetidine (Fig. 5, A and B). Similar alterations were noted for the flow parameters in these hearts when histamine was used as an agonist for the $\mathrm{H}_{2}$ receptor (Fig. 5D: original flow recordings of the aorta; Fig. 5, E and F: summarized data).

Moreover, $1 \mu \mathrm{M}$ histamine induced an increase in cell border movement (edge detection) in isolated electrically driven $(1 \mathrm{~Hz})$ ventricular cardiomyocytes (Fig. 6A). These increased movements could be blocked by cimetidine (Fig. 6A; Table 2). Furthermore, we noted increased calcium transients in ventricular cardiomyocytes from TG compared with WT stimulated by $1 \mu \mathrm{M}$ histamine. These effects were also cimetidine sensitive (Fig. 6, B and C).

With respect to signal transduction, we noted that the PIE of dimaprit in atrial preparations from TG could be reduced by additionally applying H89 [a protein kinase A (PKA) inhibitor] or W7 (a CAM kinase inhibitor, Fig. 7). Furthermore, we assessed the phosphorylation state of phospholamban. As expected, histamine increased the phosphorylation state of phospholamban in left atrial preparations from TG (freeze clamped at the maximum of the PIE, Fig. 8A). In contrast, histamine failed to increase the phosphorylation state of left atrial preparations from WT (Fig. 8A). As a positive control, isoprenaline elevated the phosphorylation state of in left atrial preparations from WT (Fig. 8A). Similar results were obtained in freeze-clamped isolated perfused heart: histamine increased the phosphorylation state of phospholamban in preparations from TG (freeze clamped at the maximum of the PIE), and this effect could be antagonized by cimetidine (Fig. 8B).

\section{Discussion}

Our integrative approach shows that we have successfully generated mice with cardiac expression of a functional $\mathrm{H}_{2}$ receptor. The starting point of this study was our unexpected finding that histamine is unable to raise force or beating rate under our experimental conditions in wild-type mouse atrial preparations. This is not without precedence, but shows again how careful you need to be to extrapolate findings from mice to man. We ourselves encountered a similar finding several years ago: when studying the effects of serotonin in human cardiac preparations (Gergs et al., 2009) we noted unexpectedly that under the very same experimental conditions where we noted a PIE of serotonin, mediated by $5 \mathrm{HT}_{4}$ receptors, using human right atrial preparations in the organ bath, we failed to detect a similar effect in mouse atrial preparations (Läer et al., 1998). Hence, we generated mice that express a functional human $5 \mathrm{HT}_{4}$ receptor and studied these mice in some detail (Gergs et al., 2010, 2013, 2017; Neumann et al., 2017). We showed a PCE and PIE in atrial preparations to serotonin in these transgenic mice (Gergs et al., 2013). We noted similar findings in isolated perfused hearts and in vivo utilizing echocardiography or invasive left ventricular hemodynamic measurements (Gergs et al., 2010). The signal transduction involved serotonin-mediated currents through L-type channels, increases in free cytosolic $\mathrm{Ca}^{2+}$, and increased PLB phosphorylation (Gergs et al., 2010).

Following a similar course of reasoning, experimental design, and methods, we herein describe the expression of a functional human $\mathrm{H}_{2}$ receptor in the mouse heart. This conclusion is based on the following evidence: histamine and more selective agonists (dimaprit and amthamine) were able to increase force of contraction in isolated atrial preparations or ventricular preparations (Langendorff hearts) of TG but not WT. In more detail, histamine is more potent at $\mathrm{H}_{3}\left(\mathrm{pEC}_{50}=7.9\right)$ and $\mathrm{H}_{4}$ receptors $\left(\mathrm{pEC}_{50}=7.92\right)$ than at $\mathrm{H}_{1}\left(\mathrm{pEC}_{50}=6.92\right)$ and $\mathrm{H}_{2}$ receptors $\left(\mathrm{pEC}_{50}=5.79\right)$ (Seifert et al., 2013). In contrast, 
A Histamine
B

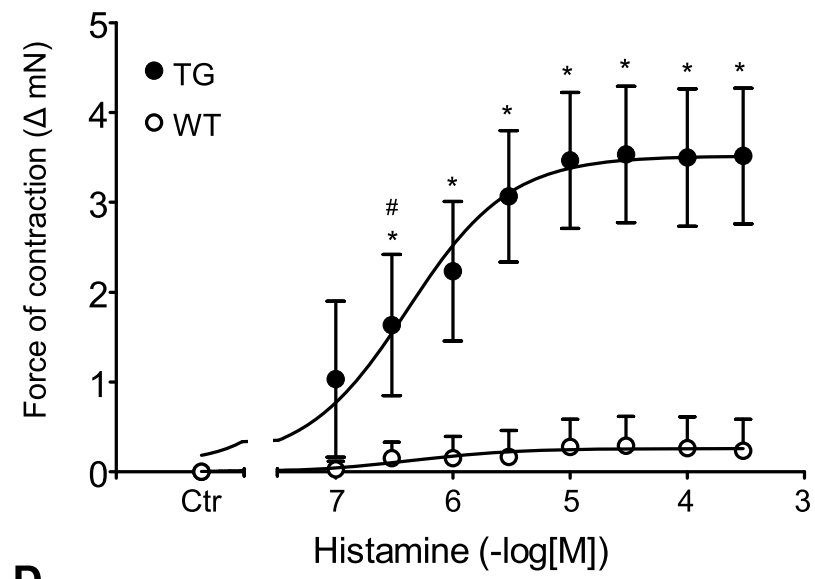

D

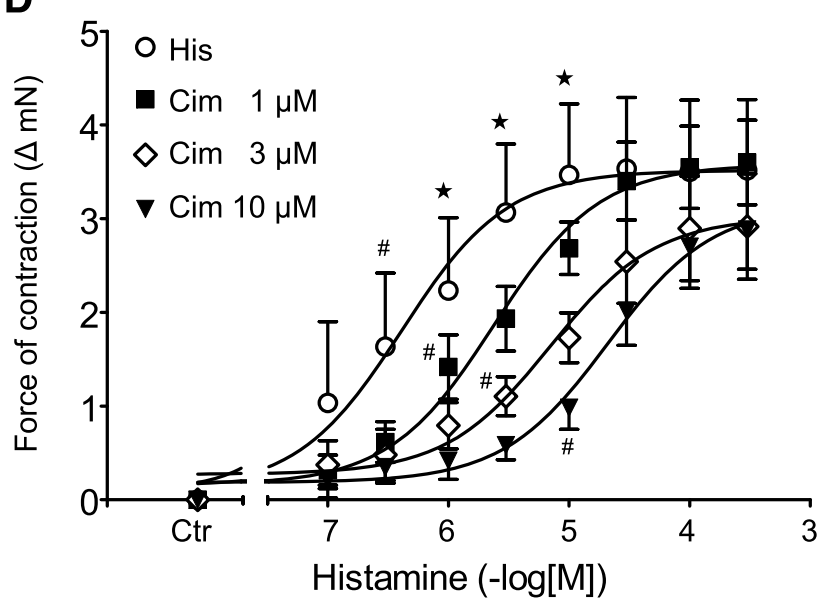

$\mathbf{E}$

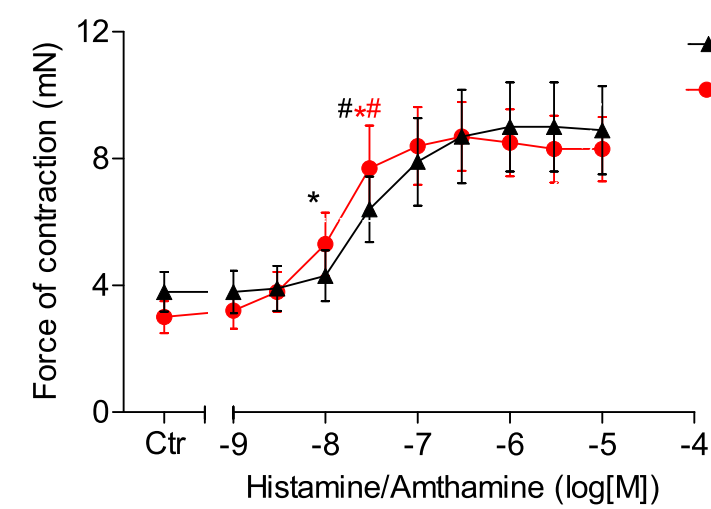

Fig. 3. Concentration-dependent PIE of histamine alone (A and B) and after preincubation (30 minutes) with the $\mathrm{H}_{2}$ receptor antagonist cimetidine $(\mathrm{C}$ and $\mathrm{D})$ in electrically driven $(1 \mathrm{~Hz})$ left atrial preparations from TG mice. WT atria did not respond to histamine. (A and C) representative original recordings; (B and D) quantification of the inotropic effects of histamine. In the presence of cimetidine, a concentration-dependent rightward shift of the inotropic effect of histamine was noted. Cim, cimetidine; His, histamine; ${ }^{\#}$ first $P<0.05$ vs. control (Ctr); ${ }^{*} P<0.05$ vs. WT; $* P<0.05$ vs. Cim $10 \mu \mathrm{M} ; n=$ 5 to 6 . (E) Histamine $(n=5)$ or amthamine $(n=4)$ induced concentration dependently a PIE in isolated electrically driven left atria of TG. $* P<0.05$ vs. $\mathrm{Ctr} ;{ }^{\#} P<0.05$ vs. WT. In isolated electrically driven left atrial preparations, dimaprit (D) exerted a concentration-dependent PIE, starting at $10 \mathrm{nM}$ and reaching plateau at $3 \mu \mathrm{M}$ with a $-\log \mathrm{EC}_{50}$ value of $6.39 \pm 0.17(n=9)$ compared with $6.73 \pm 0.16(P>0.05 ; n=5)$ for histamine $(\mathrm{F})$. The $\mathrm{EC}_{50}$ values were comparable irrespective of whether histamine and after washout dimaprit were applied or vice versa. Furthermore, $10 \mu \mathrm{M}$ cimetidine $(\mathrm{H})$ shifted the - log $\mathrm{EC}_{50}$ value of dimaprit to $4.73 \pm 0.18(P<0.05 ; n=9)$. WT atria did not respond to histamine or dimaprit. Representative original recordings of TG are shown (G and I). \#first $P<0.05$ vs. control (Ctr); $* P<0.05$ vs. WT. 
$\mathbf{F}$

Dimaprit and histamine

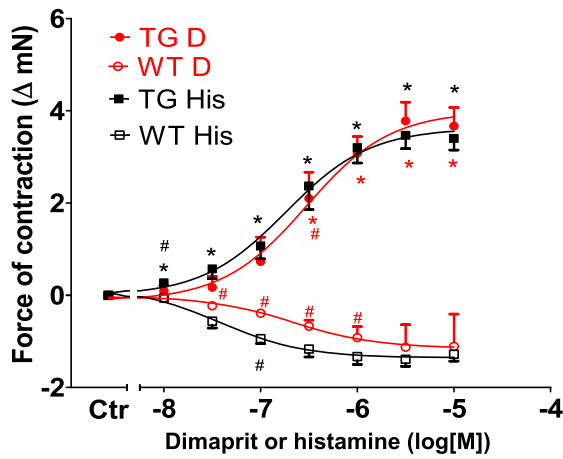

H $_{10 \mu \mathrm{M} \text { Cimetidine + dimaprit }}$

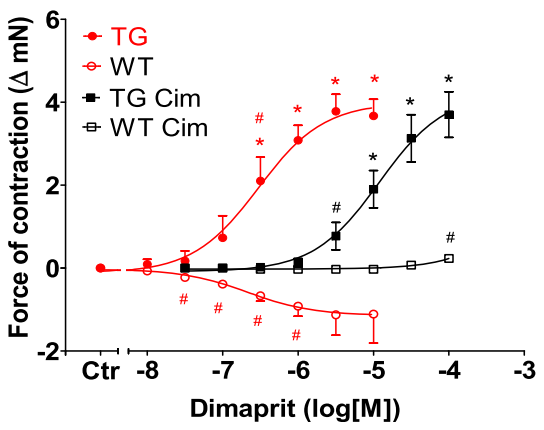

G Dimaprit

\begin{tabular}{cccccccc}
$\mathrm{Ctr}$ & 7 & 6.5 & 6 & 5.5 & 5 & 4.5 & 4 \\
$\perp$ & 1 & 1 & 1 & 1 & 1 & 1 & 1 \\
\hline
\end{tabular}

Dimaprit (-log[M])

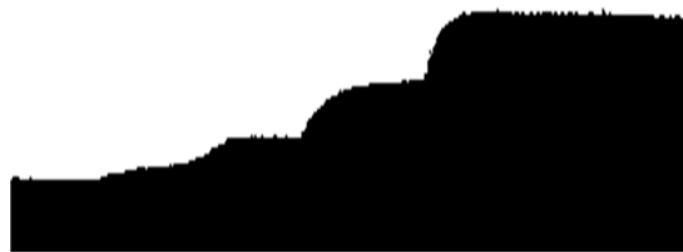

\section{I} $10 \mu \mathrm{M}$ Cimetidine + dimaprit

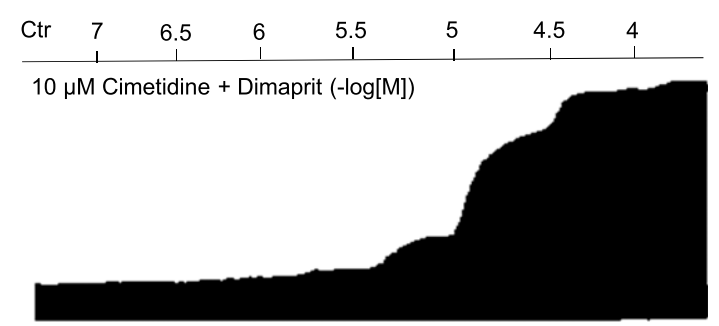

Fig. 3. Continued.

dimaprit was developed as a $\mathrm{H}_{2}$ agonist, devoid of action at $\mathrm{H}_{1}$ receptors. However, later (when $\mathrm{H}_{3}$ and $\mathrm{H}_{4}$ receptors were identified, cloned, and characterized), dimaprit was found also to be an agonist at $\mathrm{H}_{3}$ and $\mathrm{H}_{4}$ receptors. We did not detect sex differences in the responses to histamine. Amthamine was synthesized subsequently, in the search for a compound agonistic selectively at $\mathrm{H}_{2}$ receptors (Panula et al., 2015). In some systems, histamine and dimaprit were equipotent (U937 cells) (Smit et al., 1994); in other cells, histamine was more potent than dimaprit $\left(\mathrm{H}_{2}\right.$-transfected $\mathrm{CHO}$ cells) (Smit et al.,
1994). In the human heart, dimaprit was a full agonist for its PIE with an $\mathrm{EC}_{50}$ value of $43 \mu \mathrm{M}$ (Poli et al., 1994). However, in other laboratories, dimaprit was more potent for its PIE (human left atrium, right atrium, and papillary muscle) with an $\mathrm{EC}_{50}$ value around $3 \mu \mathrm{M}$ (Bristow et al., 1982; Eckel et al., 1982; Brown et al., 1986). In the guinea pig papillary muscle, amthamine was more potent and equieffective to histamine with respect to the PIE (Poli et al., 1993).

Amthamine, compared with histamine, acts as a full agonist with respect to PIE in human right atrial preparations with an
A
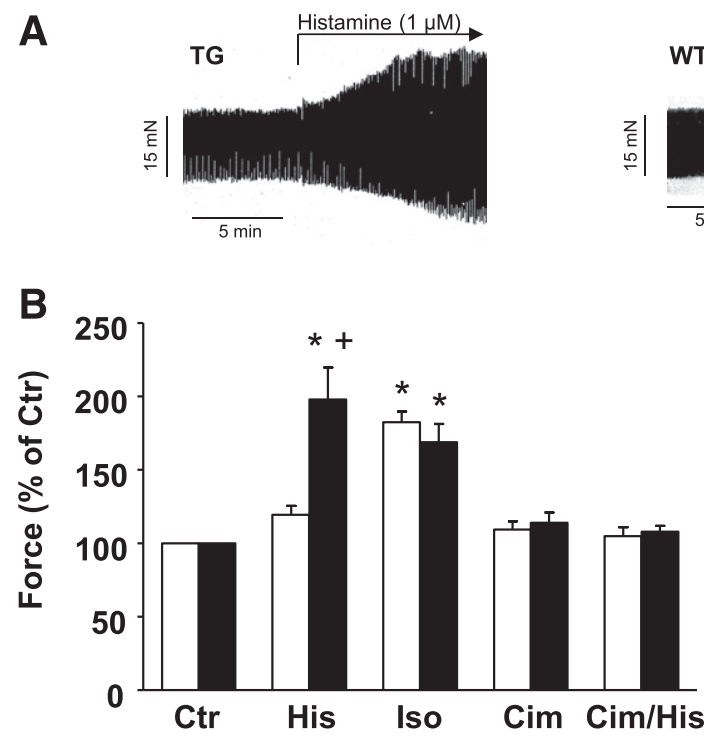

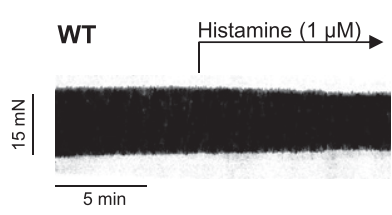

C

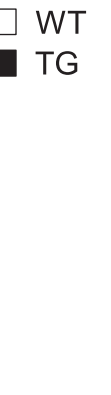

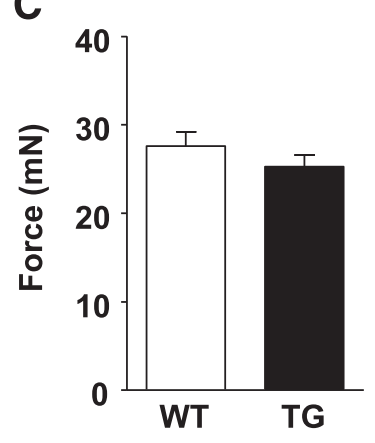

Fig. 4. Langendorff heart. (A) Representative original recordings. In isolated perfused hearts from TG mice a PIE of histamine $(1 \mu \mathrm{M})$ was noted. WT hearts did not respond to histamine. ( $\mathrm{B}$ and $\mathrm{C}$ ) Basal characteristics of force of contraction of isolated perfused heart preparations from WT and TG mice. Ctr, control; His, histamine $(1 \mu \mathrm{M})$; Iso, isoprenaline $(1 \mu \mathrm{M})$; Cim, cimetidine (10 $\mu \mathrm{M})$. (B) WT: $n=3-6$, TG: $n=3-6$, mean \pm S.E.M., ANOVA, $* P<0.05$ vs. Ctr; $+P<0.05$ vs. WT. (C) Basal force of contraction before any drug addition in WT and TG; $n=32$. 
A

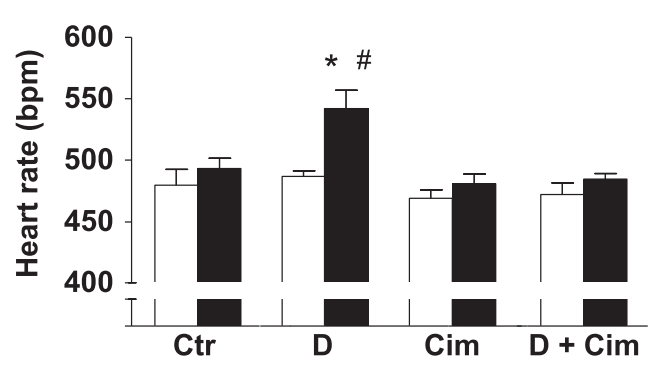

C

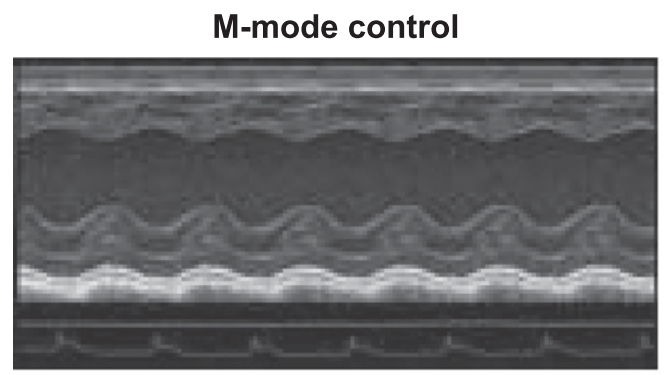

B

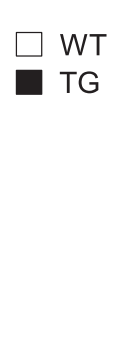

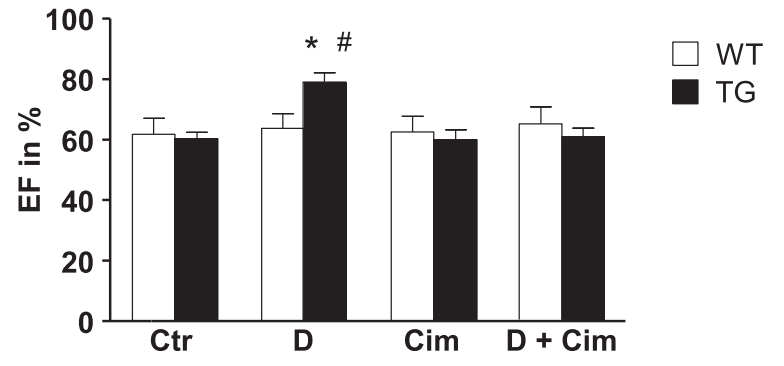

M-mode after $100 \mu \mathrm{l}$ dimaprit $(10 \mathrm{mM})$

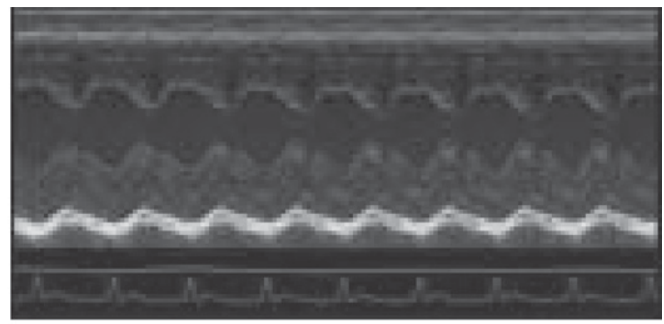

$\mathbf{E}$

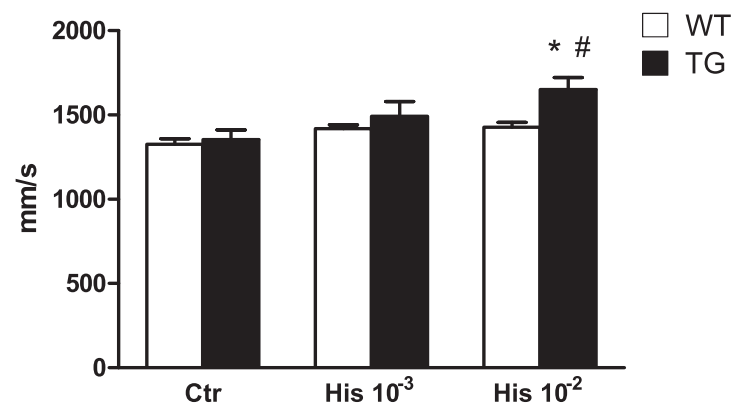

F

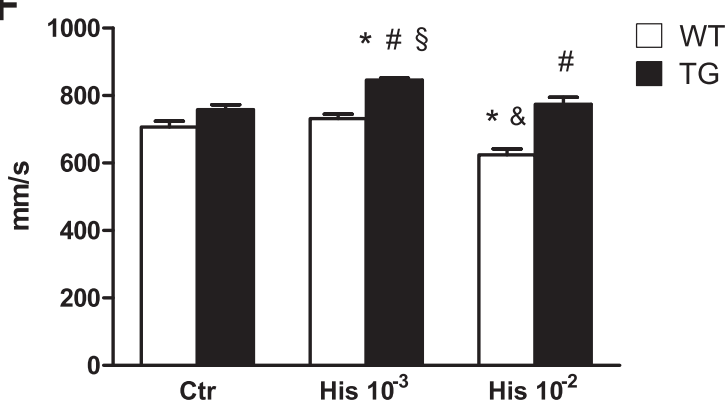

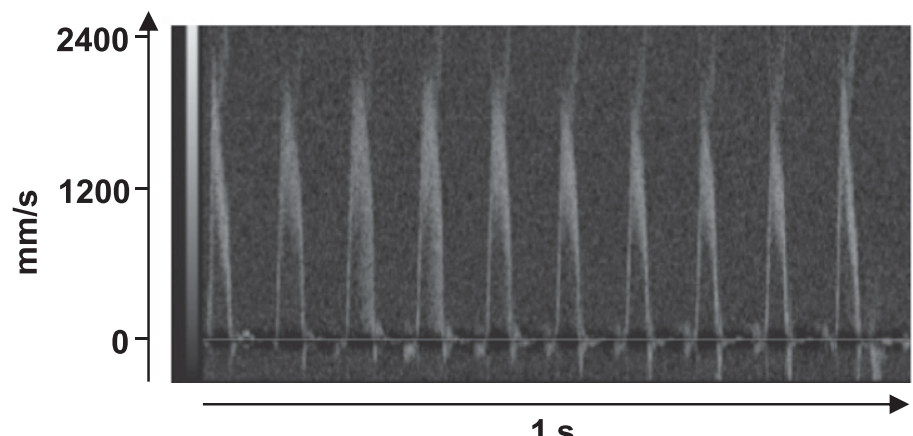

Fig. 5. Heart rate (A) and ejection fraction (B) of WT and TG measured by left ventricular echocardiography. ${ }^{\#} P<0.05$ vs. control; ${ }^{*} P<0.05$ vs. WT; $n=5-10$. (C) Original recordings of M-mode parasternal long axis view of TG without and with dimaprit [100 $\mu$ l of a solution containing 10-3M dimaprit (D) alone] or cimetidine alone [100 $\mu \mathrm{l}$ of a solution containing 10-3M cimetidine (Cim)] or both (D + Cim). Echocardiography of the ascending aorta (D and E) and the arteria pulmonalis $(\mathrm{F})$ under basal conditions [control (Ctr)] and after intraperitoneal injection of $100 \mu \mathrm{l}$ of a $1 \mathrm{mM}\left(10^{-3}\right)$ histamine and $10 \mathrm{mM}\left(10^{-2}\right)$ histamine (His), respectively. (D) Representative original recordings of the ascending aorta from TG. (E and F) Peak velocitiy in WT and TG. WT: $n=5$, TG: $n=7$, mean \pm S.E.M., ANOVA, $* P<0.05$ vs. Ctr, $\# P<0.05$ vs. WT, $\S P<0.05$ vs. His $10^{-2}, \& P<0.05$ vs. His $10^{-3}$. 
A

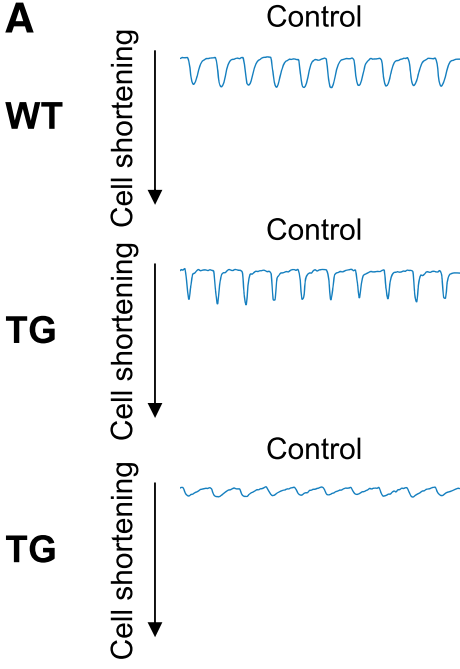

B

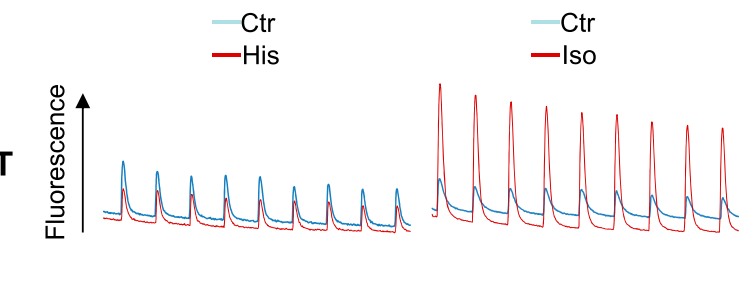

WT

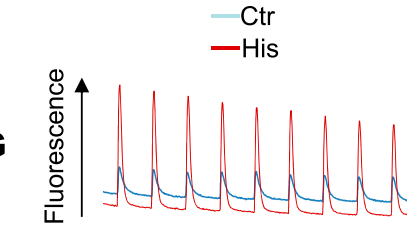

Histamine

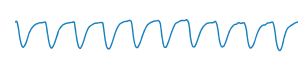

둥

Histamine

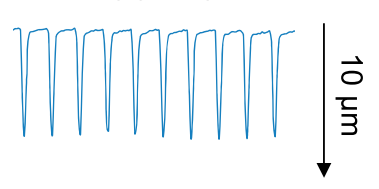

Isoprenaline

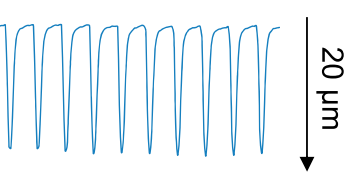

Histamine + Cimetidine

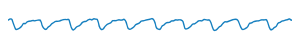

rnn

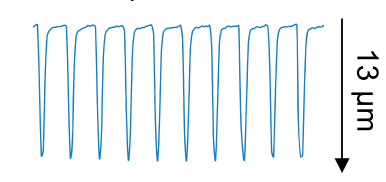

Fig. 6. (A) Representative images of cell shortening of isolated WT and TG cardiomyocytes under basal conditions [control (Ctr)] and after treatment with histamine $[($ His $), 10 \mu \mathrm{M}]$, histamine $(10 \mu \mathrm{M})+$ cimetidine [(Cim), $100 \mu \mathrm{M}]$, or isoprenaline [(Iso), $1 \mu \mathrm{M}]$. (B and C) Fluorescence intensity of calcium transients of isolated cardiomyocytes of WT and TG under basal conditions (Ctr) and after treatment with histamine $(10 \mu \mathrm{M})$, histamine $(10 \mu \mathrm{M})+$ cimetidine $(100 \mu \mathrm{M})$, or isoprenaline $(1 \mu \mathrm{M})$. (B) Representative original recordings. (C) Percentage of fluorescence intensity, WT: $n=5$ to 6 , TG: $n=3$ to 4 , mean \pm S.E.M., ANOVA, ${ }^{*} P<0.05$ vs. corresponding Ctr, ${ }^{\#} P<0.05$ vs. His WT, ${ }^{\circledR} P<0.05$ vs. Ctr and His WT, ${ }^{\S} P<0.05$ vs. His + Cim TG.

C

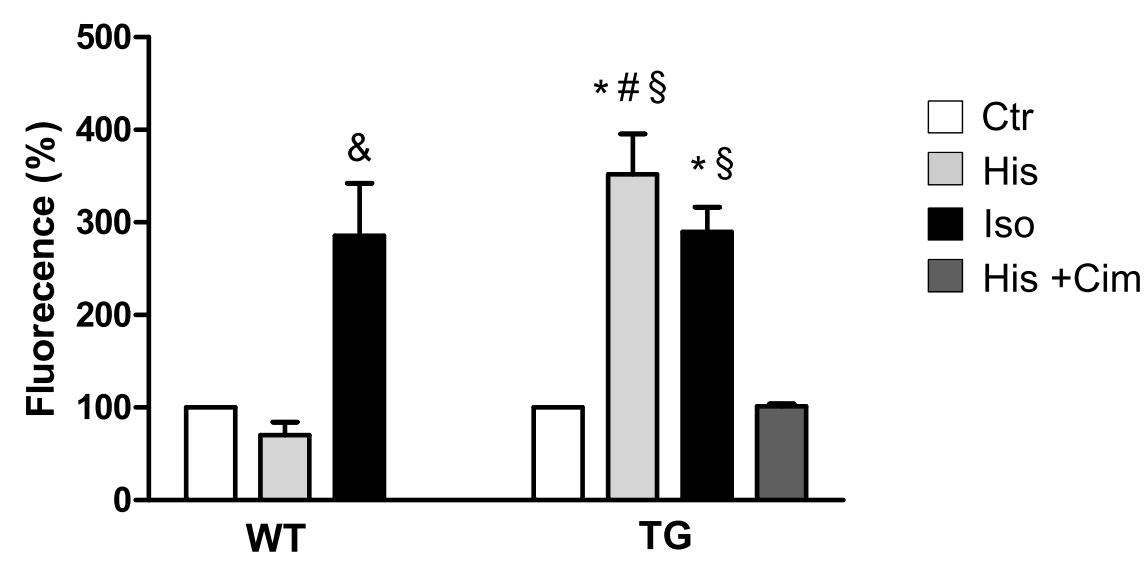

$\mathrm{EC}_{50}$ value of $4.2 \mu \mathrm{M}$ (Poli et al., 1994). In contrast, in the guinea pig right atrium amthamine was more potent than histamine with respect to the PCE (Poli et al., 1993). However, in the present work amthamine was not more potent than histamine in increasing the force of contraction (i.e., the positive inotropic effect), whereas we expected amthamine to be more potent than histamine based on the literature. The reason for this is unclear, but it is conceivable that in mouse cardiomyocytes the $\mathrm{H}_{2}$ receptor loses affinity for amthamine; however, this hypothesis remains to be tested biochemically with radioligands. Regrettably, despite considerable effort, we are hitherto unable to detect radioligand binding to $\mathrm{H}_{2}$ receptors in cardiac homogenates and cardiac membranes of TG (unpublished observations).

In the present study, the PIE of histamine in left atrial preparations was blocked by cimetidine, which is a typical $\mathrm{H}_{2}$ antagonist, and the PIE of histamine was not affected by mepyramine (= pyrilamine), a typical $\mathrm{H}_{1}$ receptor antagonist (Seifert et al., 2013). In addition, histology detects the receptor on cardiomyocytes. Furthermore, biochemical studies, 
TABLE 2

Cell shortening of WT and TG cardiomyocytes under basal conditions (control) and treated with histamine, histamine + cimetidine, or isoprenaline

WT: $n=6$, TG: $n=5-8$, mean \pm S.E.M., ANOVA, ${ }^{*} P<0.05$ vs. corresponding control, ${ }^{\#} P<0.05$ vs. histamine WT, ${ }^{\&} P<0.05$ vs. control and histamine WT, ${ }^{\circledR} P<0.05$ vs. histamine + cimetidine TG.

\begin{tabular}{lcccc}
\hline Cell Shortening & Control & His $(10 \mu \mathrm{M})$ & Iso $(1 \mu \mathrm{M})$ & His $(10 \mu \mathrm{M})+\operatorname{Cim}(100 \mu \mathrm{M})$ \\
\hline \multicolumn{1}{c}{$\mu M$} & & & \\
WT & $2.42 \pm 0.50$ & $2.31 \pm 0.49$ & $11.87 \pm 1.98^{\&}$ & \\
TG & $1.70 \pm 0.37$ & $10.22 \pm 2.28^{*, \#, \S}$ & $12.34 \pm 0.98^{*, \S}$ & $1.39 \pm 0.33$ \\
\hline
\end{tabular}

Cim, cimetidine; His, histamine; Iso, isoprenaline.

electrophysiological measurements, edge detection studies, and $\mathrm{Ca}^{2+}$ transient studies argue that the $\mathrm{H}_{2}$ receptor is present and functional in cardiomyocytes.

Moreover, PLB is only expressed in cardiomyocytes and not in noncardiomyocytes. The fact that we measured an increase in PLB phosphorylation in atrial and ventricular preparations and isolated cardiomyocytes is strongly indicative that the $\mathrm{H}_{2}$ receptors are present on and functional in cardiomyocytes. There is also other evidence for this conclusion: we used the $\alpha$ myosin promotor, which drives expression in the heart only in cardiomyocytes and not in noncardiomyocytes (Subramaniam et al., 1993).

As concerns the vascular effect, as mentioned in Introduction, there are opposite effects of histamine depending on which species and which arterial vessel is investigated. In the mouse aorta vasoconstriction by histamine was reported from independent groups (Van de Voorde and Leusen, 1984), whereas others failed to detect contraction or relaxation by histamine in precontracted isolated mouse aorta (Russell and Watts, 2000). In human coronary arteries, histamine could induce vasoconstriction via $\mathrm{H}_{1}$ receptors in smooth muscle cells, and vasodilation via $\mathrm{H}_{1}$ and $\mathrm{H}_{2}$ receptors in the endothelial cells was reported (Ginsburg et al., 1980; Vigorito et al., 1986). Vasodilation was only present in vessels with intact endothelial cells (Toda and Okamura, 1989).

In the intact mouse, low intravenous histamine did not alter the beating rate of the heart but depressed the arterial blood pressure, and higher doses of histamine led to a small increase in blood pressure but a decline in the beating rate $(\mathrm{C} 57 \mathrm{BL} / 6$ mice) (Suzuki et al., 2005). The same pattern was present in $\mathrm{H}_{1}$ knockout mice, but was lacking in $\mathrm{H}_{2}$ knockout mice or double knockout mice (Suzuki et al., 2005).

Regrettably, we cannot give the extent of expression or overexpression because the commercially available antibodies against the receptor detected signals in WT and TG to a similar extend as the expected molecular weight. This cannot be the truth because in WT no human $\mathrm{H}_{2}$ is expressed. Moreover, we cannot quantify the protein level of the endogenous receptor with antibodies. We speculate that the endogenous $\mathrm{H}_{2}$ receptor is not translated (or is protein unstable) because we can detect it using PCR but see no functional response. We cannot rule out the possibility that the endogenous receptor is present on the protein level, but lacking in cardiomyocytes or does not couple to cAMP generation in WT, which would be bewildering; we were unable to find evidence of this in the literature for the $\mathrm{H}_{2}$ receptor. Others have noted previously that the detection of heptahelical receptors such as $\mathrm{H}_{2}$ receptors in western blotting is notoriously error prone (e.g., Seifert et al., 2013); hence, our problems are not without precedence in the literature.
The fact that we measured an increase in serine 16 phosphorylation of phospholamban is easily interpreted as resulting from cAMP generation after histamine application in TG: $\mathrm{H}_{2}$ activation is expected to activate PKA, which only phosphorylates PLB on serine 16 (Simmerman et al., 1986). The inotropic effects of histamine were attenuated by both PKA and Cam kinase inhibitors (Fig. 7). This is in line with the findings for $\beta$-adrenoceptor stimulation in the heart. This leads to phosphorylation of target proteins such as phospholamban in the heart, and this phosphorylation and the concomitant increase in force of contraction is thought to be mediated by cAMP increase, subsequent activation of PKA, PKA phosphorylation of the L-type Ca channel, opening of the channel, and increase in cytosolic $\mathrm{Ca}$, and thus activation of Cam kinase and amplified phosphorylation of phospholamban and other targets (Simmerman and Jones, 1998). It can now be asked why we did not block the effects of histamine by kinase inhibitors completely (Fig. 7). The answer might be 2-fold.
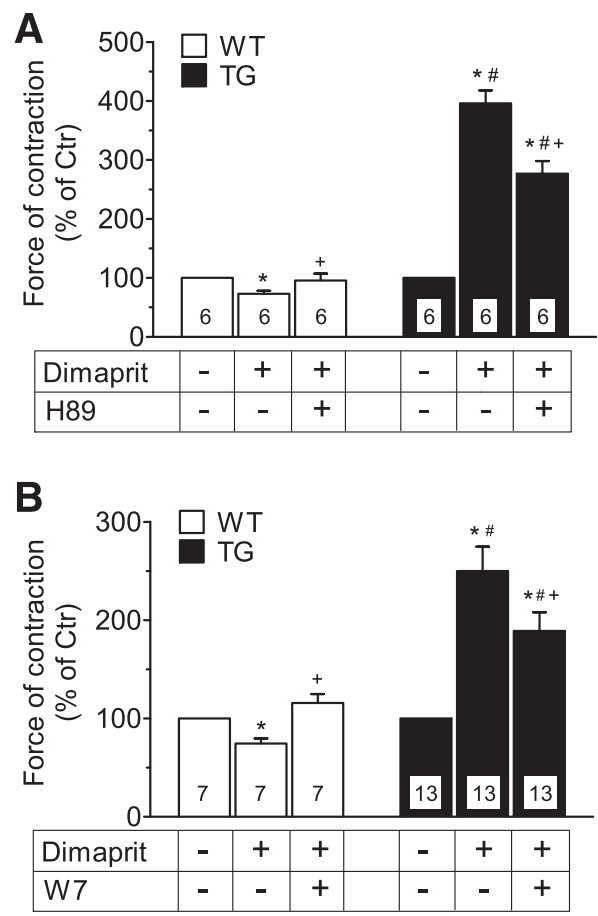

Fig. 7. Signal transduction in TG mice. The PIEs of dimaprit in isolated electrically driven left atrial preparations of TG mice were antagonized by the PKA inhibitor H89 $(50 \mu \mathrm{M})(\mathrm{A})$ or the inhibitor of the calcium calmodulin-dependent protein kinase (CaMKII) W7 $(50 \mu \mathrm{M})(\mathrm{B}) .{ }^{\#} P<$ 0.05 vs. WT; $* P<0.05$ vs. control $(\mathrm{Ctr}) ;{ }^{+} P<0.05$ vs. dimaprit; ${ }^{\circledR} P<0.05$ vs. Ctr (solvent). 
A

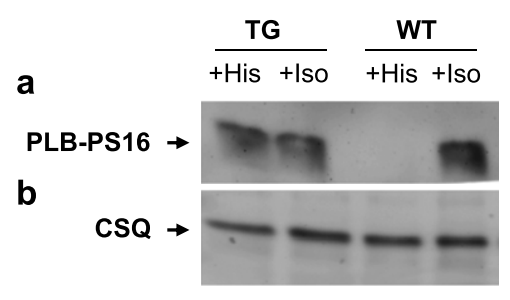

B

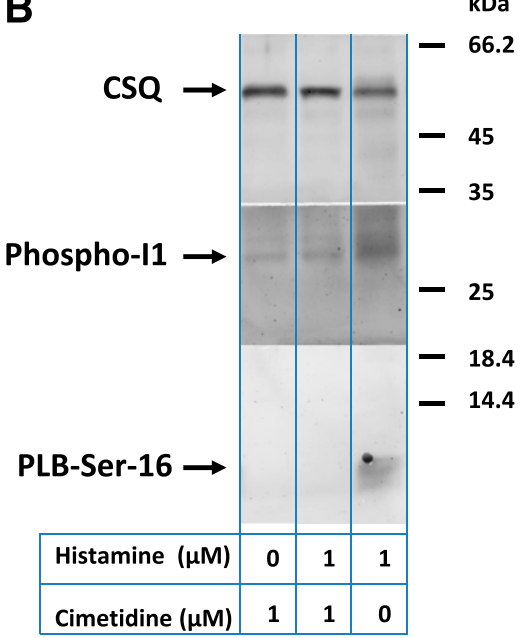

$\mathrm{kDa}$
Fig. 8. Western blotting in left atria (A) and isolated Langendorff-perfused hearts (B) histamine (His) increased phospholamban phosphorylation (PLB-PS16) and phosphatase inhibitor 1 (Phospho-I-1) in TG. Isoprenaline (Iso) increased PLB phosphorylation in both, TG and WT (A). Expression of calsequestrin (CSQ) served as loading control (A and $\mathrm{B})$.
As mentioned previously, if one kinase is blocked the other can still function and increase the function of cardiac regulatory proteins. On the other hand, we might have used a concentration of inhibitors that did not fully block the kinase of interest. However, we used concentrations of inhibitors in the heart that are within the concentrations or higher than those used by others (Yaniv et al., 2013). Moreover, kinase inhibitors lose their specificity at even higher concentrations than we used $(50 \mu \mathrm{M})$ (Simmerman and Jones, 1998). The present model is expected to offer the unique possibility of studying the human $\mathrm{H}_{2}$ receptor within a cardiac context. For instance, we have started to crossbreed our $\mathrm{H}_{2}$ and $5 \mathrm{HT}_{4}$-expressing mice to get double transgenic mice that should more closely mimic the human heart by responding in a physiologic way to both histamine and serotonin (which was the case in our initial experiments, Denise Schwarzer, not yet published). One could use this in models of systolic (e.g., using aortic banding) or diastolic heart failure.

Clinical Relevance. Surprisingly, German gynecologists were the first to study histamine (obtained as a pure drug from pharmaceutical companies) in humans. They wanted and could induce contraction of the uterus in women, but at the same time described (at a scientific meeting in Halle, Germany) many now well accepted side effects of histamine such as tachycardia (Kehrer, 1912; Jäger, 1913a,b). In healthy nonsedated humans, histamine injection led to an increase in heart rate in ECG and/or echocardiographic parameters of inotropy, which was independent of vascular effects of histamine (Watkins et al., 1982). In humans, histamine reduced aortic pressure in vivo (Vigorito et al., 1983).

In contrast to $\beta_{1}$ adrenoceptors, the density of $\mathrm{H}_{2}$ receptors in failing human hearts was not changed compared with nonfailing controls [ventricular samples from transplants in Munich, Germany, where tritiated tiotipine was used in binding studies (Baumann et al., 1984)]. In isolated ventricular preparations from failing human hearts some studies did not detect a reduced PIE to histamine compared with nonfailing controls (Baumann et al., 1982, 1983, 1984), and it was suggested that $\mathrm{H}_{2}$ agonists might be clinically useful in the treatment of heart failure. Baumann et al. (1984) and Felix et al. (1995) even tested $\mathrm{a}_{2}$ receptor agonist (impromidine) in the intensive care unit in patients and described beneficial acute effects. In contrast, others noted a reduced PIE to histamine in samples from failing human hearts (Brown et al., 1986; Böhm et al., 1988). A correlation between $\mathrm{H}_{2}$ mutation and heart failure was investigated, but could not be substantiated, in contrast to a correlation between $\mathrm{H}_{3}$ mutation and heart failure in Han Chinese patients (He et al., 2016).

There are interesting data suggesting that $\mathrm{H}_{2}$ receptor antagonists reduce the propensity for heart failure in humans. Apparently, the first data in this regard were Japanese register data (Kim et al., 2004); this prompted a better controlled but still retrospective study in the United States (Leary et al., 2014, 2016b). The authors provided first evidence for a beneficial role of $\mathrm{H}_{2}$ receptor antagonists by delaying the onset of heart failure and alterations of the morphology of the heart; the development of left ventricular dilation, a hallmark of imminent heart failure, was delayed. Furthermore, Leary and Bristow (2016) and Leary et al. (2016a) suggested that this might be an example of repurposing of drugs (histamine receptor antagonists) for heart failure. In a subsequent analysis, Leary et al., 2018 suggested that it might be possible to identify a subgroup of patients with risk of heart failure that might benefit particularly from treatment with $\mathrm{H}_{2}$ receptor antagonists.

\section{Acknowledgments}

We thank Maria Beer-Krön Pia Willmy, Sonja Reber and Dita Frisch for expert technical assistance. This paper is dedicated to the memory of Dr. A. Buschauer (University of Regensburg).

\section{Authorship Contributions}

Participated in research design: Gergs, Neumann.

Conducted experiments: Bernhardt, Buchwalow, Edler, Fröba, Keller, Kirchhefer, Köhler, Mißlinger, Wache.

Performed data analysis: Bernhardt, Köhler, Buchwalow, Fröba, Mißlinger, Wache, Neumann.

Wrote or contributed to the writing of the manuscript: Gergs, Neumann, Fröba.

\section{References}

Ackermann D (1910) Über den bakteriellen Abbau des Histidins. Z Physiol Chem 65: $504-510$.

Aldi S, Takano K, Tomita K, Koda K, Chan NY, Marino A, Salazar-Rodriguez M, Thurmond RL, and Levi R (2014) Histamine $\mathrm{H}_{4}$-receptors inhibit mast cell renin release in ischemia/reperfusion via protein kinase $\mathrm{C} \varepsilon$-dependent aldehyde dehydrogenase type-2 activation. $J$ Pharmacol Exp Ther 349:508-517.

Bartlet AL (1963) The action of histamine on the isolated heart. Br J Pharmacol Chemother 21:450-461. 
Baumann G, Felix SB, Riess G, Loher U, Ludwig L, and Blömer H (1982) Effective stimulation of cardiac contractility and myocardial metabolism by impromidine and dimaprit-two new H2-agonistic compounds-in the surviving, catecholamineinsensitive myocardium after coronary occlusion. $J$ Cardiovasc Pharmacol 4 542-553.

Baumann G, Mercader D, Busch U, Felix SB, Loher U, Ludwig L, Sebening H Heidecke CD, Hagl S, Sebening F, et al. (1983) Effects of the H2-receptor agonist impromidine in human myocardium from patients with heart failure due to mitral and aortic valve disease. J Cardiovasc Pharmacol 5:618-625.

Baumann G, Permanetter B, and Wirtzfeld A (1984) Possible value of $\mathrm{H}_{2}$-receptor agonists for treatment of catecholamine-insensitive congestive heart failure. Pharmacol Ther 24:165-177.

Baumeister P, Erdmann D, Biselli S, Kagermeier N, Elz S, Bernhardt G, and Buschauer A (2015) [ $\left[{ }^{3} \mathrm{H}\right] \mathrm{UR}-\mathrm{DE} 257$ : development of a tritium-labeled squaramide-type selective histamine $\mathrm{H}_{2}$ receptor antagonist. ChemMedChem 10:83-93.

Böhm M, Beuckelmann D, Brown L, Feiler G, Lorenz B, Näbauer M, Kemkes B, and Erdmann E (1988) Reduction of beta-adrenoceptor density and evaluation of positive inotropic responses in isolated, diseased human myocardium. Eur Heart $J$ 9:844-852.

Bristow MR, Cubicciotti R, Ginsburg R, Stinson EB, and Johnson C (1982) Histamine-mediated adenylate cyclase stimulation in human myocardium. $\mathrm{Mol}$ Pharmacol 21:671-679.

Brown L, Lorenz B, and Erdmann E (1986) Reduced positive inotropic effects in diseased human ventricular myocardium. Cardiovasc Res 20:516-520.

Buchwalow I, Samoilova V, Boecker W, and Tiemann M (2011) Non-specific binding of antibodies in immunohistochemistry: fallacies and facts. Sci Rep 1:28.

Dai S (1976) A study of the actions of histamine on the isolated rat heart. Clin Exp Pharmacol Physiol 3:359-367.

Dale HH and Laidlaw PP (1910) The physiological action of $\beta$-iminazolylethylamine. J Physiol 41:318-344.

Dale HH and Laidlaw PP (1911) Further observations on the action of $\beta$-iminazolylethylamine. J Physiol 43:182-195.

Eckel L, Gristwood RW, Nawrath H, Owen DA, and Satter P (1982) Inotropic and electrophysiological effects of histamine on human ventricular heart muscle. $J$ Physiol 330:111-123.

Einis W (1913) Über die Wirkung des Pituitrins und $\beta$-Imidazoläthylamins (Histamins) auf die Herzaktion. Biochem Zeitschr 52:96-117.

Felix SB, Buschauer A, and Baumann G (1995) Haemodynamic profile of new H2 receptor agonists in congestive heart failure. Eur J Clin Invest 25 (Suppl 1):42-46.

Flacke W, Atanacković D, Gillis RA, and Alper MH (1967) The actions of histamine on the mammalian heart. J Pharmacol Exp Ther 155:271-278.

Genovese A, Gross SS, Sakuma I, and Levi R (1988) Adenosine promotes histamine H1-mediated negative chronotropic and inotropic effects on human atrial myocardium. J Pharmacol Exp Ther 247:844-849.

Gergs U, Baumann M, Böckler A, Buchwalow IB, Ebelt H, Fabritz L, Hauptmann S, Keller N, Kirchhof P, Klöckner U, et al. (2010) Cardiac overexpression of the human 5-HT 4 receptor in mice. Am J Physiol Heart Circ Physiol 299:H788-H798.

Gergs U, Berndt T, Buskase J, Jones LR, Kirchhefer U, Müller FU, Schlüter KD, Schmitz W, and Neumann J (2007) On the role of junctin in cardiac $\mathrm{Ca}^{2+}$ handling, contractility, and heart failure. Am J Physiol Heart Circ Physiol 293:H728-H734.

Gergs U, Böckler A, Ebelt H, Hauptmann S, Keller N, Otto V, Pönicke K, Schmitz W, and Neumann J (2013) Human 5- $\mathrm{HT}_{4}$ receptor stimulation in atria of transgenic mice. Naunyn Schmiedebergs Arch Pharmacol 386:357-367.

Gergs U, Boknik P, Buchwalow I, Fabritz L, Matus M, Justus I, Hanske G, Schmitz W, and Neumann J (2004) Overexpression of the catalytic subunit of protein phosphatase 2A impairs cardiac function. J Biol Chem 279:40827-40834.

Gergs U, Fritsche J, Fabian S, Christ J, and Neumann J (2017) Desensitization of the human $5-\mathrm{HT}_{4}$ receptor in isolated atria of transgenic mice. Naunyn Schmiedebergs Arch Pharmacol 390:987-996.

Gergs U, Kirchhefer U, Buskase J, Kiele-Dunsche K, Buchwalow IB, Jones LR Schmitz W, Traub O, and Neumann J (2011) Sarcoplasmic reticulum $\mathrm{Ca}^{2+}$ release in neonatal rat cardiac myocytes. J Mol Cell Cardiol 51:682-688.

Gergs U, Neumann J, Simm A, Silber RE, Remmers FO, and Läer S (2009) Phosphorylation of phospholamban and troponin I through 5-HT 4 receptors in the isolated human atrium. Naunyn Schmiedebergs Arch Pharmacol 379:349-359.

Ginsburg R, Bristow MR, Stinson EB, and Harrison DC (1980) Histamine receptors in the human heart. Life Sci 26:2245-2249.

Goren N, Perez Leiros C, Sterin-Borda L, and Borda E (1994) Effect of histamine in autoimmune myocarditis mice. Int J Immunopharmacol 16:737-745.

Goren N, Sterin-Borda L, Leiros CP, and Borda ES (1995) Increases in cyclic AMP levels couple to $\mathrm{H} 1$ receptors in atria from autoimmune myocarditis mice. Cell Signal 7:759-764.

Haas HL, Sergeeva OA, and Selbach O (2008) Histamine in the nervous system. Physiol Rev 88:1183-1241.

Hattori Y, Gando S, Endou M, and Kanno M (1991) Characterization of histamine receptors modulating inotropic and biochemical activities in rabbit left atria. Eur $J$ Pharmacol 196:29-36.

Hattori Y, Nakaya H, Endou M, and Kanno M (1990) Inotropic, electrophysiological and biochemical responses to histamine in rabbit papillary muscles: evidence for coexistence of H1- and H2-receptors. J Pharmacol Exp Ther 253:250-256.

Hattori Y, Sakuma I, and Kanno M (1988) Differential effects of histamine mediated by histamine $\mathrm{H}_{1}$ - and $\mathrm{H}_{2}$-receptors on contractility, spontaneous rate and cyclic nucleotides in the rabbit heart. Eur J Pharmacol 153:221-229.

He GH, Cai WK, Zhang JB, Ma CY, Yan F, Lu J, and Xu GL (2016) Associations of polymorphisms in $H R H 2, H R H 3, D A O$, and HNMT genes with risk of chronic heart failure. BioMed Res Int 2016:1208476.

Jäger F (1913a) Ein neuer, für die Praxis brauchbarer Sekaleersatz (Tenosin). Münch Med Wochenschr 31:1714-1715.

Jäger F (1913b) Versuche zur Verwendung des $\beta$-Imidazolyläthylamins in der Geburtshilfe. Zentralbl Gynakol 8:265-269.
Jutel M, Akdis M, and Akdis CA (2009) Histamine, histamine receptors and their role in immune pathology. Clin Exp Allergy 39:1786-1800.

Kehrer E (1912) Die motorischen Funktionen des Uterus und ihre Beeinflussung durch Wehenmittel. Munch Med Wochenschr 33:1831-1833.

Keller M, Pop N, Hutzler C, Beck-Sickinger AG, Bernhardt G, and Buschauer A (2008) Guanidine-acylguanidine bioisosteric approach in the design of radioligands: synthesis of a tritium-labeled $N^{\mathrm{G}}$-propionylargininamide $\left({ }^{3} \mathrm{H}\right]-\mathrm{UR}$ MK114) as a highly potent and selective neuropeptide $\mathrm{Y} \mathrm{Y}_{1}$ receptor antagonist. $J$ Med Chem 51:8168-8172.

Kim J, Washio T, Yamagishi M, Yasumura Y, Nakatani S, Hashimura K, Hanatani A, Komamura K, Miyatake K, Kitamura S, et al. (2004) A novel data mining approach to the identification of effective drugs or combinations for targeted endpoints-application to chronic heart failure as a new form of evidence-based medicine. Cardiovasc Drugs Ther 18:483-489

Kirchhefer U, Baba HA, Kobayashi YM, Jones LR, Schmitz W, and Neumann J (2002) Altered function in atrium of transgenic mice overexpressing triadin 1. Am J Physiol Heart Circ Physiol 283:H1334-H1343.

Kirchhefer U, Brekle C, Eskandar J, Isensee G, Kučerová D, Müller FU, Pinet F, Schulte JS, Seidl MD, and Boknik P (2014) Cardiac function is regulated by B56 $\alpha$ mediated targeting of protein phosphatase $2 \mathrm{~A}$ (PP2A) to contractile relevant substrates. J Biol Chem 289:33862-33873.

Klein I and Levey GS (1971) Activation of myocardial adenyl cyclase by histamine in guinea pig, cat, and human heart. J Clin Invest 50:1012-1015.

Köhler F, Kirchhefer U, Gergs U, and Neumann J (2013) Phenotype of mice with cardiac overexpression of histamine H2-receptors (Abstract). Naunyn Schmiedebergs Arch Pharmacol 386 (Suppl 1):S43.

Koyama M, Seyedi N, Fung-Leung WP, Lovenberg TW, and Levi R (2003) Norepinephrine release from the ischemic heart is greatly enhanced in mice lacking histamine $\mathrm{H}_{3}$ receptors. Mol Pharmacol 63:378-382.

Läer S, Remmers F, Scholz H, Stein B, Müller FU, and Neumann J (1998) Receptor mechanisms involved in the 5-HT-induced inotropic action in the rat isolated atrium. Br J Pharmacol 123:1182-1188.

Laher I and McNeill JH (1980a) Effects of histamine on rat isolated atria. Can $J$ Physiol Pharmacol 58:1114-1116.

Laher I and McNeill JH (1980b) Effects of histamine in the isolated kitten heart. Can J Physiol Pharmacol 58:1256-1261.

Leary PJ, Barr RG, Bluemke DA, Bristow MR, Kronmal RA, Lima JA, Ralph DD, Ventetuolo CE, and Kawut SM $(2014) \mathrm{H}_{2}$ receptor antagonists and right ventricular morphology: the MESA right ventricle study. Ann Am Thorac Soc 11:1379-1386.

Leary PJ and Bristow MR (2016) Reply: is histamine $\mathrm{H}_{2}$ receptor a real promising target for prevention or treatment of heart failure? $J$ Am Coll Cardiol 68: 2029-2030.

Leary PJ, Kronmal RA, Bluemke DA, Buttrick PM, Jones KL, Kao DP, Kawut SM Krieger EV, Lima JA, Minobe W, et al. (2018) Histamine $\mathrm{H}_{2}$ receptor polymorphisms, myocardial transcripts, and heart failure (from the multi-ethnic study of atherosclerosis and beta-blocker effect on remodeling and gene expression trial). Am J Cardiol 121:256-261.

Leary PJ, Ralph DD, Tedford RJ, and Kronmal RA (2016a) Reply: histamine H2 receptors and heart failure: a complex cross-talk. J Am Coll Cardiol 68:775-776.

Leary PJ, Tedford RJ, Bluemke DA, Bristow MR, Heckbert SR, Kawut SM, Krieger EV, Lima JA, Masri CS, Ralph DD, et al. (2016b) Histamine $\mathrm{H}_{2}$ receptor antagonists, left ventricular morphology, and heart failure risk: the MESA study. $J A m$ Coll Cardiol 67:1544-1552.

Levi R, Malm JR, Bowman FO, and Rosen MR (1981) The arrhythmogenic actions of histamine on human atrial fibers. Circ Res 49:545-550.

Liu X, Callaerts-Vegh Z, Evans KL, and Bond RA (2002) Chronic infusion of betaadrenoceptor antagonist and inverse agonists decreases elevated protein kinase $\mathrm{A}$ activity in transgenic mice with cardiac-specific overexpression of human beta 2-adrenoceptor. J Cardiovasc Pharmacol 40:448-455.

Matsuda N, Jesmin S, Takahashi Y, Hatta E, Kobayashi M, Matsuyama K, Kawakami N, Sakuma I, Gando S, Fukui $\mathrm{H}$, et al. (2004) Histamine $\mathrm{H}_{1}$ and $\mathrm{H}_{2}$ receptor gene and protein levels are differentially expressed in the hearts of rodents and humans. J Pharmacol Exp Ther 309:786-795.

Meister J, Gergs U, and Neumann J (2014) Effects of dimaprit in H2 receptor overexpressing mice (Abstract). Naunyn-Schmiedeberg's Arch Pharmacol 387 (Suppl 1):S67.

Meister J, Weisgut J, Gergs U, and Neumann J (2015) Human H2 receptors in a mouse model and the endogenous cardiac histamine content (Abstract). Acta Physiologica 215:S705

National Research Council (2011) Guide for the Care and Use of Laboratory Animals, 8th ed, The National Academies Press, Washington, DC.

Neumann J, Hofmann B, and Gergs U (2017) Production and function of serotonin in cardiac cells, in Serotonin-A Chemical Messenger Between All Types of Living Cells (Shad KF ed) pp 271-305. Rijeka, Croatia.

Neumann J, Köhler F, Kirchhefer U, Höft A, Buchwalow I, and Gergs U (2013) Initial characterization of histamine H2-receptor overexpressing mice (Abstract). FASEB J 27:1096.14

Neumann J, Meister J, Stössel S, Buchwalow IB, Kaever V, and Gergs U (2014) Characterization of $\mathrm{H} 2$ histamine-receptor overexpressing mice (Abstract). Inflamm Res 63 (Suppl 1):S48

Neumann J, Meister J, Weisgut J, Künstler B, and Gergs U (2015) Further characterization of $\mathrm{H} 2$ overexpressing mice (Abstract). Inflamm Res 64 (Suppl 1):S48.

Panula P, Chazot PL, Cowart M, Gutzmer R, Leurs R, Liu WL, Stark H, Thurmond RL, and Haas HL (2015) International union of basic and clinical pharmacology. XCVIII. Histamine receptors. Pharmacol Rev 67:601-655.

Parsons ME and Ganellin CR (2006) Histamine and its receptors. Br J Pharmacol 147 (Suppl 1):S127-S135.

Poli E, Pozzoli C, Coruzzi G, Bertaccini G, and Timmerman H (1993) In vitro cardiac pharmacology of the new histamine $\mathrm{H}_{2}$-receptor agonist amthamine: comparisons with histamine and dimaprit. Agents Actions 40:44-49. 
Poli E, Pozzoli C, Spaggiari I, and Bertaccini G (1994) Positive inotropic activity of the novel histamine $\mathrm{H}_{2}$-receptor agonist, amthamine, on the human heart in vitro. Gen Pharmacol 25:1649-1654.

Russell A and Watts S (2000) Vascular reactivity of isolated thoracic aorta of the C57BL/6J mouse. J Pharmacol Exp Ther 294:598-604.

Sanders L, Lynham JA, and Kaumann AJ (1996) Chronic beta 1-adrenoceptor blockade sensitises the $\mathrm{H} 1$ and $\mathrm{H} 2$ receptor systems in human atrium: rôle of cyclic nucleotides. Naunyn Schmiedebergs Arch Pharmacol 353:661-670.

Schenk P (1921) Über die Wirkungsweise des $\beta$-Imidazoläthylamins (Histamins) auf den menschlichen Organismus. Arch exp Pathol Pharmacol 89:332-339.

Seifert R, Strasser A, Schneider EH, Neumann D, Dove S, and Buschauer A (2013) Molecular and cellular analysis of human histamine receptor subtypes. Trends Pharmacol Sci 34:33-58.

Simmerman HK, Collins JH, Theibert JL, Wegener AD, and Jones LR (1986) Sequence analysis of phospholamban. Identification of phosphorylation sites and two major structural domains. J Biol Chem 261:13333-13341.

Simmerman HK and Jones LR (1998) Phospholamban: protein structure, mechanism of action, and role in cardiac function. Physiol Rev 78:921-947.

Smit MJ, Leurs R, Shukrula SR, Bast A, and Timmerman H (1994) Rapid desensitization of the histamine H2 receptor on the human monocytic cell line U937. Eur $J$ Pharmacol 288:17-25.

Subramaniam A, Gulick J, Neumann J, Knotts S, and Robbins J (1993) Transgenic analysis of the thyroid-responsive elements in the $\alpha$-cardiac myosin heavy chain gene promoter. J Biol Chem 268:4331-4336.

Suzuki H, Mobarakeh JI, Nunoki K, Sukegawa J, Watanabe H, Kuramasu A, Watanabe T, Yanai K, and Yanagisawa T (2005) Effects of activation of central nervous histamine receptors in cardiovascular regulation; studies in $\mathrm{H}_{1}$ and $\mathrm{H}_{2}$ receptor gene knockout mice. Naunyn Schmiedebergs Arch Pharmacol 371:99-106.

Thoren FB, Aurelius J, and Martner A (2011) Antitumor properties of histamine in vivo. Nat Med 17:537, author reply 537-538.
Toda N and Okamura T (1989) Endothelium-dependent and -independent responses to vasoactive substances of isolated human coronary arteries. Am J Physiol 257: H988-H995.

Van de Voorde J and Leusen I (1984) Effect of histamine on aorta preparations of different species. Arch Int Pharmacodyn Ther 268:95-105.

Vigorito C, Poto S, Picotti GB, Triggiani M, and Marone G (1986) Effect of activation of the $\mathrm{H} 1$ receptor on coronary hemodynamics in man. Circulation 73:1175-1182.

Vigorito C, Russo P, Picotti GB, Chiariello M, Poto S, and Marone G (1983) Cardiovascular effects of histamine infusion in man. J Cardiovasc Pharmacol 5:531-537. Watkins J, Dargie HJ, Brown MJ, Krikler DM, and Dollery CT (1982) Effects of histamine type 2 receptor stimulation on myocardial function in normal subjects. Br Heart $J$ 47:539-545.

Wellner-Kienitz MC, Bender K, Meyer T, and Pott L (2003) Coupling to $G_{s}$ and $G_{q / 11}$ of histamine $\mathrm{H}_{2}$ receptors heterologously expressed in adult rat atrial myocytes. Biochim Biophys Acta 1642:67-77.

Windaus A and Vogt W (1907) Synthese des Imidazolyläthylamins. Ber Dtsch Chem Ges 40:3691-3695

Yaniv Y, Spurgeon HA, Ziman BD, and Lakatta EG (2013) $\mathrm{Ca}^{2+} /$ calmodulindependent protein kinase II (CaMKII) activity and sinoatrial nodal pacemaker cell energetics. PLoS One 8:e57079.

Zerkowski HR, Broede A, Kunde K, Hillemann S, Schäfer E, Vogelsang M, Michel MC, and Brodde OE (1993) Comparison of the positive inotropic effects of serotonin, histamine, angiotensin II, endothelin and isoprenaline in the isolated human right atrium. Naunyn Schmiedebergs Arch Pharmacol 347:347-352.

Address correspondence to: J. Neumann, Institut für Pharmakologie und Toxikologie, Medizinische Fakultät, Martin-Luther-Universität Halle-Wittenberg, Magdeburger Str. 4, 06112 Halle (Saale), Germany. E-mail: joachim.neumann@ medizin.uni-halle.de 